\title{
Influence of genetic dissimilarity of mother and fetus on progesterone concentrations in pregnant mice and adaptive features of offspring
}

\author{
L. A. Gerlinskaya and V. I. Evsikov \\ Institute of Systematics and Ecology of Animals, Siberian Branch of Russian Academy \\ Science, 630091, Novosibirsk, Frunze str., 11, Russia
}

\begin{abstract}
Concentrations of progesterone in blood plasma and tissue were studied in pregnant mice of strains BALB/cLac and C57BL/6J. Both intra- and interstrain mating and embryo transplantations were used as models of homo- and heterotopic pregnancy. On day 4 of heterotopic pregnancy, plasma progesterone concentrations of females of both strains were higher than those in females of both strains undergoing homotopic pregnancy. In addition, tissue progesterone content of hybrid embryos was higher than that of purebred embryos. Adrenocortical responses to
\end{abstract}

social conflict as indicators of stress resistance were studied in progeny aged 2-3 months. There was a minimal increase in plasma glucocorticoid concentrations in heterotopic transplantants after $\mathbf{1 5}$ min pair-matching tests and 30 min crowding compared with those of other progeny, including purebred male mice of BALB/cLac and C57BL/6J strains, homotransplantants and reciprocal hybrids. Thus, genetic dissimilarity of mother and fetuses plays an important role in progesterone provision during pregnancy and also modifies development of progeny.

\section{Introduction}

During mammalian pregnancy tight morphological and physiological inter-relationships are established between the mother and her fetuses and these inter-relationships are mediated primarily by their genetic and antigenic differences. The immune basis for mother-offspring interrelationships occurs during the early stages of pregnancy, as $\mathrm{H}-2$ and $\mathrm{H}$-2-like antigens are found at the two-blastomere stage in mouse embryos (Krco and Goldberg, 1977; Cozard and Warner, 1981; Warner et al., 1988; Duc-Goiran et al., 1999). Despite previous ideas about immune attack on fetal allografts (Medawar, 1953), this dissimilarity is more beneficial for than deleterious to embryonic development (Billington, 1964; Fernandez et al., 1999). Hybrid pregnancy could serve as a model to demonstrate the role of antigen differences in establishing morphofunctional mother-fetus interactions and development of offspring. However, changes in embryonic development that are due to heterosis cannot be excluded.

This problem can be avoided by interstrain transplantation of early embryos, allowing modelling of hybrid pregnancy (Evsikov and Morozova, 1977, 1978; Evsikov et al., 1991) and study of ontogenetic effects on purebred offspring (Carlier et al., 1992). In this way, a strict line of demarcation between the effects of epigenetic (determined by mother-fetus inter-relationships) and genetic factors on the development of adaptive features in offspring can be established. Studies involving homotopic

Email: peg@eco.nsc.ru and heterotopic transfer of mouse blastocysts have shown that viability of the progeny often depends on genetically determined differences, including antigenic distinctions between the embryos and the mother (Billington, 1964; Evsikov et al., 1972; Evsikov and Morozova, 1977, 1978). These conditions contribute significantly to the effect of heterosis on growth of hybrid progeny that is observed during heterozygous pregnancies. Joint transfer of embryos of different strains revealed growth stimulation of not only heterotopic but also homotopic embryos (Vagina, 1997).

Progesterone is the main female hormone responsible for the trophic maintenance of embryo development (Michael et al., 1975; Barkley et al., 1979; Heap et al., 1979; Wilmut et al., 1986). Progesterone also plays an important role in the control of the response of the maternal immune system to embryonic antigens (Grossman, 1984; Szekeres-Bartho et al., 1991; Spina et al., 1998). In particular, the local immunosuppressive action of high concentrations of progesterone in implantation sites helps in the successful development of immunogenetically distinct embryos (Munroe, 1971; Clemens et al., 1979; Siiteri and Stites, 1982). Some potential immuno-endocrine mechanisms responsible for additional increases in plasma progesterone concentrations during heterotopic pregnancy have been identified, including production of chorionic gonadotrophin by the peripheral mononuclear cells that form mucosaassociated lymphocyte tissues (MALT) in the Fallopian tubes and endometrium (Morris et al., 1985, 1986). Local or general allogenic stimulation induces secretion of gonadotrophin by mononuclear cells (Alexander et al., 1998) that can enhance the increase in plasma progesterone 
concentrations. Another mechanism of immune-dependent increase in progesterone secretion may be connected with the anti-luteolytic effects of some cytokines, such as type I interferon-tau, which prevents destruction of the corpus luteum by inhibiting the output of a luteolytic hormone, $\mathrm{PGF}_{2 \alpha}$ (Mathialagan and Roberts, 1994).

It is well documented that intrauterine conditions not only affect embryonic growth, but also make significant contributions to the establishment of adaptive properties of adult offspring. In particular, the endocrine status of pregnant females has significant effects on the subsequent stress resistance of the adult offspring (Dygalo and Naumenko, 1985; Naumenko and Maslova, 1985; Aliev and Guseinova, 1986; Kinsley and Svare, 1986; Dygalo, 1988; Henry et al., 1994; McCormic et al., 1995).

Although many facts indicating the influence of genetic differences between mother and fetus on embryo development are known, the role of maternal endocrine function in these effects remains unknown. It is also unclear how intrauterine conditions during homo- and heterotopic pregnancy affect the adaptive features of offspring.

The aim of the present study was to analyse endocrine changes in mothers and offspring that result from genetic differences between mother and fetus. Progesterone content in blood, uterine and embryonic tissues after intra- and interstrain crosses of BALB/CLac $\left(\mathrm{H}-2^{\mathrm{d}}\right)$ and $\mathrm{C} 57 \mathrm{BL} / 6 \mathrm{~J}\left(\mathrm{H}-2^{\mathrm{b}}\right)$ mice with different major histocompatibility complex loci and after homotopic and heterotopic transfer of embryos, was examined. These strains are used traditionally in studies of mother-fetus immunogenetic dissimilarity (Billington, 1964; Evsikov et al., 1972; Evsikov and Morozova, 1977, 1978). Adrenocortical reaction to stress in adult offspring was also studied.

\section{Materials and Methods}

\section{Animals and maintenance}

The mouse strains used, C57BL/6J and BALB/CLac, were bred at the Microbiology Research Centre 'Vector' in Novosibirsk. Animals were kept in plastic cages on a $14 \mathrm{~h}$ light:10 h dark schedule at $20-22^{\circ} \mathrm{C}$. Water and food were available ad libitum. Males were maintained singly and females were kept in groups ( $n=5$ per cage). Experiments were started not earlier than 3 weeks after the mice were obtained. Mice aged 2-3 months were used in the crossing experiments.

\section{Mating and transfer}

Oestrous females were placed with males of the same or of the other strain overnight. In the morning the females were examined and detection of a vaginal plug was considered to represent day 0 of pregnancy. Pregnant females were placed in individual cages. Other females were mated with vasectomized males and were used later as recipients of transferred embryos. Pseudopregnancy was determined by the presence of a vaginal plug. Two days later these females were used as embryo recipients. The embryos were transferred to mice under sodium pentobarbitol (Nembutal; Medpreperat Company, Novosibirsk) narcosis (40 $\mathrm{mg} \mathrm{g}^{-1}$ body weight). BALB/cLac and $\mathrm{C} 57 \mathrm{BL} / 6 \mathrm{~J}$ embryos (72-84 $\mathrm{h}$ of development) were transferred to pseudopregnant BALB/CLac and C57BL/6] females. Donor females did not undergo superovulation. About 5-8 blastocysts were washed from the uterus of each of two donor mice using $0.1 \mathrm{ml}$ TCM-199 and the blastocysts were collected by Pasteur capillary under a microscope. The blastocysts were transferred to the right horn of the uterus of the recipient females. The influence of operative manipulation on plasma progesterone concentrations was studied in 22 females of the BALB/CLac strain that were mated with males of the same strain, underwent a sham operation and received an injection of TCM-199 into the uterus.

\section{Progesterone in blood and tissues}

The endocrine effects of homo- and heterotopic pregnancy were studied at implantation (day 4) and at the time of penetration of the endometrium by the trophoblast (day 7; see Duc-Goiran et al., 1999). On days 4 and 7 of pregnancy, the mice were decapitated and blood samples were collected to obtain plasma. Embryos were extracted from the uterus and the parts of the uterus located between implantation sites were cut out and weighed. All procedures were performed on ice. Day 4 embryos were extracted and weighed with the implantation sites, as it was difficult to separate embryonic and uterine tissue; however, day 7 embryos were freed from the fetal membrane. Tissues were homogenized in phosphate buffer ( $\mathrm{pH}$ 7.4). Plasma and tissue homogenates were frozen before radioimmunoassay. Plasma and tissue samples were assayed for progesterone concentrations using commercially available radioimmunoassay kits (steron-P-125-J; Institute of Bioorganic Chemistry of the Byelorussian Academy of Sciences). An excluding extraction analysis was made according to the manufacturer's instructions. A uniform extraction procedure preceded the radioimmunoassay: $50 \mu \mathrm{l}$ plasma or $300 \mu \mathrm{l}$ tissue homogenates were extracted with $3 \mathrm{ml}$ ethyl ether; $2 \mathrm{ml}$ extracts were removed, transferred to new tubes, vacuum dried at $37^{\circ} \mathrm{C}$ and $300 \mu \mathrm{l}$ phosphate buffer $(\mathrm{pH}$ 7.0) were added. The extraction yield was checked for every set of assays using $\left[{ }^{3} \mathrm{H}\right]$-labelled steroids and varied from 85 to $95 \%$. The sensitivity of the assays determined from $95 \%$ confidence limits of zero standards was100 $\mathrm{pg} \mathrm{ml}^{-1}$. A fivepoint, two-fold dilution series of plasma or tissue samples in phosphate buffer was constructed and compared with standard curves of progesterone to determine parallelism. There were no significant differences between the slopes of standard curves and the slopes of lines generated by assaying samples.

\section{Offspring study}

The adrenocortical response to stress was studied in six 
Table 1. Plasma progesterone concentrations before and during the early stage of pregnancy in female mice mated with males of the same or a different genotype

\begin{tabular}{|c|c|c|c|c|}
\hline \multicolumn{2}{|c|}{ Genotype } & \multicolumn{3}{|c|}{ Plasma progesterone concentration $\left(\mathrm{ng} \mathrm{ml}^{-1}\right)$} \\
\hline Female & Male & Before mating & Day 4 of pregnancy & Day 7 of pregnancy \\
\hline BALB/cLac & $\begin{array}{l}\text { BALB/cLac } \\
\text { C57BL/6J }\end{array}$ & $1.8 \pm 0.4(n=11)$ & $\begin{array}{l}21.9 \pm 1.3(n=62)^{\mathrm{b}} \\
28.7 \pm 2.0(n=46)^{\mathrm{a}}\end{array}$ & $\begin{array}{l}30.5 \pm 2.3(n=68) \\
27.1 \pm 2.7(n=41)\end{array}$ \\
\hline C57BL/6J & $\begin{array}{l}\text { C57BL/6J } \\
\text { BALB/cLac }\end{array}$ & $4.8 \pm 1.0(n=11)$ & $\begin{array}{l}21.8 \pm 1.8(n=55)^{\mathrm{b}} \\
28.8 \pm 2.1(n=43)^{\mathrm{a}}\end{array}$ & $\begin{array}{l}29.3 \pm 2.7(n=53) \\
27.7 \pm 2.0(n=42)\end{array}$ \\
\hline
\end{tabular}

Values are mean $\pm \mathrm{SE}$.

One-way ANOVA: day 4 of pregnancy: $F=4.93, P<0.01$; day 7 of pregnancy: $F=0.38$.

${ }^{a b}$ Different superscripts within a column indicate significant differences between values (LSD test, $P<0.05$ ).

male groups derived from different schemes of mating or embryo transfer (see above). Group C: progeny of purebred mating of BALB/CLac mice; group B: progeny of purebred mating of $\mathrm{C} 57 \mathrm{BL} / 6 \mathrm{~J}$ mice; group $\mathrm{CB}$ : progeny of interstrain mating of BALB/cLac (female) and C57BL/6J (male) mice; group $\mathrm{BC}$ : progeny purebred mating of $\mathrm{C} 57 \mathrm{BL} / 6 \mathrm{~J}$ (female) and BALB/CLac (male) mice; group T-C: BALB/cLac mice obtained from homotopic embryo transfer to female BALB/cLac mice; and group T-B: C57BL/6J mice obtained from heterotopic embryo transfer to female BALB/cLac mice.

After weaning, male mice were kept in groups $(n=5$ per cage) for 1.5-2.0 months. For minimization of the hierarchydependent behavioural and physiological differences, experimental males were put into single cages 4 weeks before Expts 1 and 2 .

Expt 1 was done in May-June. Pair-matched tests (15 $\mathrm{min}$ ) in an arena (diameter $50 \mathrm{~cm}$ ) were used as models of social conflict. Pairs were selected from mice within the same group with similar body weights. There were 26 males in group C, 30 in group B, 12 in group CB, 14 in group BC, 29 in group T-C and 27 in group T-B.

Expt 2 was done in November-December. One male from each experimental group was crowded with 5-6 males from other groups for $30 \mathrm{~min}$ in the neutral arena. There were 14 males from groups $C, B, C B, B C$ and $T-B$, and four males from group T-C.

Blood samples were taken from the retro-orbital sinus on the day before testing and immediately after testing. It took $<2$ min to collect each blood sample. Thus, the stressful effect of handling was avoided because the increase in blood glucocorticoid concentrations starts only 3-5 min after the beginning of stress impact (Brown and Martin 1974; Kiochisa et al., 1977). The concentration of 11oxycorticosteroids (11-OHCS) in plasma was measured by fluorometry (Udenfriend, 1965; Balashov, 1990).

\section{Statistical analysis}

In mating experiments three-way ANOVA was used to determine the effects of parent genotypes, day of pregnancy and their interactions on the concentrations of progesterone in plasma and tissue. The same statistical procedure was also used to analyse progesterone variations in experiments with embryo transfer. The effects of maternal and embryonic genotypes and day of pregnancy were evaluated. Two-way ANOVA (group of male and experimental conditions) was used in a study of the adrenocortical responses of offspring to social stress. Differences between groups were assessed by one-way ANOVA with subsequent comparison of means by the LSD test. Student's $t$ test was used for comparison of the two groups. Spearman's rank order correlation (rho) was used to determine inter-relationships between measures.

\section{Results}

Progesterone concentrations in plasma and tissue during early stages of homo- or heterotopic pregnancy

Intra- and interstrain crossing. Significant increases in plasma progesterone concentrations were observed on days 4 and 7 of pregnancy for all crosses (Table 1). According to three-way ANOVA, parent genotype did not influence the plasma progesterone concentrations $\left(F_{1402}=0.032\right.$ and $P=0.80$ for males; $F_{1402}=0.001$ and $P=0.95$ for females). At the same time, significant effects of the day of pregnancy $\left(F_{1402}=7.04\right.$ and $\left.P=0.007\right)$ and interactions of these factors $\left(F_{1402}=9.68\right.$ and $\left.P=0.002\right)$ were found. Progesterone concentrations on day 4 of pregnancy were higher in females that carried hybrid embryos than in females undergoing homotopic pregnancy. On day 7 of pregnancy the concentrations of progesterone were increased relative to day 4 only in cases of homotopic pregnancy and, hence, the differences in plasma progesterone between homotopic and heterotopic pregnancies were no longer observed.

Plasma progesterone concentrations in pregnant females depend on the number of embryos (Michael et al., 1975; Barkley et al., 1979). In the present study, the mean number of embryos per female was the same for intra- and interstrain crosses $(F=1.77, P=0.15)$. An association between plasma progesterone concentrations in the mother and the number of embryos was found on day 7 of homotopic pregnancy: in BALB/CLac: rho $=0.43(n=47$; $P<0.01$ ) during homotopic pregnancy and rho $=0.11$ 
Table 2. Concentrations of progesterone in the uterus before or during the early stage of pregnancy in female mice mated with males of the same or a different genotype

\begin{tabular}{|c|c|c|c|c|}
\hline \multicolumn{2}{|c|}{ Genotype } & \multicolumn{3}{|c|}{ Uterine progesterone content $\left(\mathrm{ng} \mathrm{mg}^{-1}\right)$} \\
\hline Female & Male & Before mating & Day 4 of pregnancy & Day 7 of pregnancy \\
\hline $\mathrm{BALB} / \mathrm{cLac}$ & $\begin{array}{l}\text { BALB/CLac } \\
\text { C57BL/6] }\end{array}$ & $0.6 \pm 0.1(n=13)$ & $\begin{array}{l}0.6 \pm 0.1(n=20)^{\mathrm{b}} \\
1.2 \pm 0.3(n=16)^{\mathrm{a}}\end{array}$ & $\begin{array}{l}2.0 \pm 0.2(n=34)^{\mathrm{b}} \\
3.2 \pm 0.6(n=29)^{\mathrm{a}}\end{array}$ \\
\hline $\mathrm{C} 57 \mathrm{BL} / 6 \mathrm{~J}$ & $\begin{array}{l}\text { C57BL/6J } \\
\text { BALB/cLac }\end{array}$ & $0.6 \pm 0.2(n=13)$ & $\begin{array}{l}0.8 \pm 0.1(n=14)^{\mathrm{ab}} \\
1.1 \pm 0.1(n=14)^{\mathrm{a}}\end{array}$ & $\begin{array}{l}3.3 \pm 0.4(n=32)^{\mathrm{a}} \\
3.3 \pm 0.4(n=23)^{\mathrm{a}}\end{array}$ \\
\hline
\end{tabular}

Values are mean $\pm \mathrm{SE}$.

One-way ANOVA: day 4 of pregnancy: $F=3.51, P<0.02$; day 7 of pregnancy: $F=2.66, P<0.05$.

${ }^{\mathrm{ab}}$ Different superscripts within a column indicate significant differences between values (LSD test, $P<0.05$ ).

Table 3. Concentration of progesterone in embryo tissue before or during the early stage of pregnancy in female mice mated with males of the same or a different genotype

\begin{tabular}{|c|c|c|c|}
\hline \multicolumn{2}{|c|}{ Genotype } & \multicolumn{2}{|c|}{ Embryonic progesterone content $\left(\mathrm{ng} \mathrm{mg}^{-1}\right)$} \\
\hline Female & Male & Day 4 of pregnancy & Day 7 of pregnancy \\
\hline \multirow[t]{2}{*}{$\mathrm{BALB} / \mathrm{cLac}$} & $\mathrm{BALB} / \mathrm{CLac}$ & $0.8 \pm 0.1(n=21)$ & $2.5 \pm 0.3(n=27)^{\mathrm{b}}$ \\
\hline & $\mathrm{C} 57 \mathrm{BL} / 6 \mathrm{~J}$ & $1.3 \pm 0.1(n=14)^{*}$ & $3.8 \pm 0.6(n=24)^{\mathrm{a} *}$ \\
\hline \multirow[t]{2}{*}{$\mathrm{C} 57 \mathrm{BL} / 6 \mathrm{~J}$} & $\mathrm{C} 57 \mathrm{BL} / 6 \mathrm{~J}$ & $1.2 \pm 0.1(n=15)$ & $1.6 \pm 0.2(n=25)^{\mathrm{b}}$ \\
\hline & $\mathrm{BALB} / \mathrm{CLac}$ & $1.2 \pm 0.2(n=15)$ & $2.8 \pm 0.5(n=14)^{\mathrm{ab} * *}$ \\
\hline
\end{tabular}

Values are mean $\pm \mathrm{SE}$.

One-way ANOVA: day 4 of pregnancy: $F=2.14, P=0.1$; day 7 of pregnancy: $F=5.66, P<0.002$ :

${ }^{* *} P<0.01$ and $* P<0.05$ compared with purebred embryo (Student's $t$ test).

${ }^{\mathrm{ab}}$ Different superscripts within a column indicate significant differences between values (LSD test, $P<0.05$ ).

( $n=41)$ during heterotopic pregnancy; in C57BL/6): rho = $0.31(n=49 ; \quad P<0.05)$ and rho $=0.10 \quad(n=40)$ in homotopic and heterotopic pregnancies, respectively. In summary, during homotopic pregnancy there is a clear interaction between maternal progesterone concentrations and number of embryos; no such interaction was observed during heterotopic pregnancy.

Three-way ANOVA indicated a highly significant effect of day of pregnancy on the progesterone content in uterine tissue $\left(F_{1174}=46.94\right.$ and $\left.P<0.001\right)$. Progesterone contents were increased by day 7 of pregnancy in all crosses (Table 2). The progesterone contents of BALB/CLac females were higher on days 4 and 7 of heterotopic pregnancy then during homotopic pregnancy. In C57BL/6J females progesterone content of uterine tissues did not depend on pregnancy type.

Progesterone content in embryonic tissues varied with the day of pregnancy $\left(F_{1147}=39.67\right.$ and $\left.P<0.001\right)$, interactions of parent genotypes $\left(F_{1147}=5.84\right.$ and $P=0.001)$ and interactions among the three factors $\left(F_{1147}\right.$ $=4.35$ and $P=0.039$ ). The progesterone content had increased by day 7 of pregnancy (Table 3). The progesterone content of tissues of hybrid embryos was higher than that of purebred pregnancies of BALB/CLac mothers on days 4 and 7 of pregnancy. In the pair-wise comparison of progesterone content in embryos of $\mathrm{C} 57 \mathrm{BL} / 6 \mathrm{~J}$ mothers, hormone content was higher in day 7 hybrids than in purebred embryos.

Pseudopregnancy. On day 4 of pseudopregnancy, the concentrations of plasma progesterone in BALB/CLac females mated with vasectomized BALB/CLac or C57BL/6) males were $20.8 \pm 2.6 \mathrm{ng} \mathrm{ml}^{-1}(n=29)$ and $23.4 \pm 2.5 \mathrm{ng}$ $\mathrm{ml}^{-1} \quad(n=26)$, respectively. Progesterone concentrations decreased to $4.9 \pm 2.1 \mathrm{ng} \mathrm{ml}^{-1}(n=12)$ and $6.0 \pm 3.2 \mathrm{ng}$ $\mathrm{ml}^{-1}(n=13)$ on day 7 of pseudopregnancy (the concentrations typically observed in oestrous mice). On day 4 of pseudopregnancy, progesterone content in the uterus was $4.1 \pm 0.1 \mathrm{ng} \mathrm{mg}^{-1}(n=13)$ after intrastrain and 1.1土 $0.1 \mathrm{ng} \mathrm{mg}^{-1}(n=13)$ after interstrain mating. However, on day 7 of pseudopregnancy these values had decreased to $0.8 \pm 0.4 \mathrm{ng} \mathrm{mg}^{-1}(n=13)$ and $0.8 \pm 0.1 \mathrm{ng} \mathrm{mg}^{-1}(n=13)$, respectively.

Intra- and interstrain embryo transfers. Three-way ANOVA showed significant effects of maternal $\left(F_{1145}=14.50\right.$ and $\left.P<0.001\right)$ and embryonic $\left(F_{1145}=3.89\right.$ and $P=0.051)$ genotypes and interactions of all three factors $\left(F_{1145}=5.68\right.$ and $\left.P=0.018\right)$ on plasma progesterone concentrations in pregnant females. Plasma progesterone concentrations on day 4 of pregnancy were dependent on the genotypes of both the mother and the embryos transferred (Table 4). As in the case of interstrain crosses the 
Table 4. Plasma progesterone concentrations in pregnant female mice after intra- and interstrain embryo transfer

\begin{tabular}{|c|c|c|c|c|}
\hline \multirow[b]{2}{*}{ Operation } & \multicolumn{2}{|c|}{ Genotype } & \multicolumn{2}{|c|}{ Progesterone concentration $\left(\mathrm{ng} \mathrm{ml}^{-1}\right)$} \\
\hline & Mother & Embryo & Day 4 of pregnancy & Day 7 of pregnancy \\
\hline \multirow[t]{4}{*}{ Transfer } & $\mathrm{BALB} / \mathrm{cLac}$ & $\mathrm{BALB} / \mathrm{cLac}$ & $19.9 \pm 2.5(n=27)^{\mathrm{b}}$ & $15.7 \pm 2.6(n=24)^{b}$ \\
\hline & & C57BL/6J & $27.8 \pm 2.9(n=31)^{\mathrm{a}}$ & $19.1 \pm 1.8(n=25)^{\mathrm{b}}$ \\
\hline & $\mathrm{C} 57 \mathrm{BL} / 6 \mathrm{~J}$ & C57BL/6J & $17.6 \pm 3.2(n=6)^{\mathrm{ab}}$ & $37.7 \pm 5.3(n=10)^{\mathrm{a}}$ \\
\hline & & $\mathrm{BALB} / \mathrm{cLac}$ & $29.6 \pm 2.6(n=16)^{\mathrm{a} *}$ & $29.3 \pm 2.7(n=14)^{\mathrm{a}}$ \\
\hline Sham operation & $\mathrm{BALB} / \mathrm{cLac}$ & $\mathrm{BALB} / \mathrm{cLac}$ & $18.9 \pm 3.2(n=22)^{\mathrm{b}}$ & $17.7 \pm 2.5(n=16)^{\mathrm{b}}$ \\
\hline
\end{tabular}

Values are mean $\pm \mathrm{SE}$.

One-way ANOVA: day 4 of pregnancy: $F=2.50, P<0.05$; day 7 of pregnancy: $F=8.75, P<0.001 .{ }^{*} P=0.06$ in comparison of homotopic pregnancy with heterotopic pregnancy in female $\mathrm{C} 57 \mathrm{BL} / 6 \mathrm{~J}$ mice (Student's $t$ test).

${ }^{\mathrm{ab}}$ Different superscripts within a column indicate significant differences between values (LSD test, $P<0.05$ ).

Table 5. Concentration of progesterone in the uterus of pregnant female mice after intra- and interstrain embryo transfer

\begin{tabular}{|c|c|c|c|}
\hline \multicolumn{2}{|c|}{ Genotype } & \multicolumn{2}{|c|}{ Uterine progesterone content $\left(\mathrm{ng} \mathrm{mg}^{-1}\right)$} \\
\hline Mother & Embryo & Day 4 of pregnancy & Day 7 of pregnancy \\
\hline \multirow{2}{*}{$\mathrm{BALB} / \mathrm{CLac}$} & $\mathrm{BALB} / \mathrm{cLac}$ & $1.1 \pm 0.2(n=13)^{b}$ & $1.9 \pm 0.2(n=26)^{\mathrm{c}}$ \\
\hline & $\mathrm{C} 57 \mathrm{BL} / 6 \mathrm{~J}$ & $0.9 \pm 0.2(n=11)^{b}$ & $3.1 \pm 0.6(n=29)^{b}$ \\
\hline \multirow[t]{2}{*}{$\mathrm{C} 57 \mathrm{BL} / 6 \mathrm{~J}$} & $\mathrm{C} 57 \mathrm{BL} / 6 \mathrm{~J}$ & $2.4 \pm 0.3(n=8)^{\mathrm{a}}$ & $5.1 \pm 0.7(n=11)^{\mathrm{a}}$ \\
\hline & $\mathrm{BALB} / \mathrm{cLac}$ & $2.3 \pm 0.2(n=17)^{\mathrm{a}}$ & $3.5 \pm 0.4(n=14)^{\mathrm{ab}}$ \\
\hline
\end{tabular}

Values are mean $\pm \mathrm{SE}$.

One-way ANOVA: day 4 of pregnancy: $F=18.18, P<0.001$; day 7 of pregnancy: $F=5.39, P<0.005$.

${ }^{a b c}$ Different superscripts within a column indicate significant differences between values (LSD test, $P<0.05$ ).

concentration of progesterone tended to be higher after heterotopic transfer than after homotopic transfer. On day 7 of pregnancy these differences were not significant.

The sham operation on BALB/CLac females did not affect progesterone concentrations on day 4 of pregnancy. The hormone concentration in sham-operated females was the same as in females with transferred homotopic embryos and in intact females mated with males of the same genotype (Table 1). On day 7 of pregnancy, sham females had the same plasma progesterone concentration as did females with transferred homotopic embryos, but the progesterone concentration was lower than in intact pregnant females of the BALB/CLac strain $(P<0.001)$. These differences could be due to smaller numbers of fetuses in sham-operated females, which had fewer embryos $(5.37 \pm 0.79)$ than did intact BALB/CLac females $(7.96 \pm 0.41 ; P<0.005)$. These data indicate that surgery had no effect on maternal production of progesterone.

According to three-way ANOVA the progesterone content of the uterus is dependent on the maternal $\left(F_{1121}=\right.$ 22.84 and $P<0.001)$ and embryonic $\left(F_{1121}=6.36\right.$ and $P=0.013)$ genotypes. Uterine progesterone content was higher in C57BL/6J females than in BALB/CLac females on day 4 of pregnancy (Table 5). On day 7 of pregnancy the hormone concentration in the uterus of BALB/CLac strain mice was higher during heterotopic pregnancy than homotopic pregnancy. Uterine progesterone content in C57BL/6J females was the same after intra- and interstrain embryo transfer.

Three-way ANOVA showed significant effects of maternal genotype $\left(F_{1119}=14.61\right.$ and $\left.P<0.001\right)$ and day of pregnancy $\left(F_{1119}=33.71\right.$ and $\left.P<0.001\right)$ on progesterone content in embryonic tissues. On day 4 of pregnancy embryonic progesterone content was highest in BALB/CLac embryos transferred to C57BL/6J females (Table 6). This difference was not significant on day 7 of pregnancy.

These data show that plasma progesterone concentrations during the implantation stage (day 4 of pregnancy) depend on genetic differences between the mother and fetus. Progesterone concentrations were lower during homotopic pregnancy than in interstrain crosses or heterotopic transfer for female BALB/cLac mice. Uterine progesterone content was higher during heterotopic pregnancy than during homotopic pregnancy. Differences in progesterone content in hybrid embryos were observed between heterotopic and homotopic transplants on day 4 of pregnancy in embryos transferred to C57BL/6J mothers only.

Therefore, genetic differences between a mother and her fetuses appear to play a key role in the formation of the endocrine status of pregnant females. This effect could lead 
Table 6. Progesterone content in embryonic tissue of pregnant female mice after intra- and interstrain embryo transfer

\begin{tabular}{|c|c|c|c|}
\hline \multicolumn{2}{|c|}{ Genotype } & \multicolumn{2}{|c|}{ Embryonic progesterone content $\left(\mathrm{ng} \mathrm{mg}^{-1}\right)$} \\
\hline Mother & Embryo & Day 4 of pregnancy & Day 7 of pregnancy \\
\hline \multirow[t]{2}{*}{ BALB/cLac } & $\mathrm{BALB} / \mathrm{cLac}$ & $1.3 \pm 0.2(n=11)^{\mathrm{b}}$ & $4.7 \pm 0.6(n=25)$ \\
\hline & C57BL/6J & $1.6 \pm 0.3(n=16)^{\mathrm{b}}$ & $4.1 \pm 0.6(n=29)$ \\
\hline \multirow[t]{2}{*}{$\mathrm{C} 57 \mathrm{BL} / 6 \mathrm{~J}$} & $\mathrm{C} 57 \mathrm{BL} / 6 \mathrm{~J}$ & $2.2 \pm 0.5(n=5)^{\mathrm{b}}$ & $6.5 \pm 1.0(n=11)$ \\
\hline & $\mathrm{BALB} / \mathrm{cLac}$ & $3.9 \pm 0.5(n=17)^{\mathrm{a}}$ & $6.0 \pm 1.2(n=13)$ \\
\hline
\end{tabular}

Values are mean $\pm \mathrm{SE}$

One-way ANOVA: day 4 of pregnancy: $F=11.69, P<0.001$; day 7 of pregnancy: $F=2.11, P=0.11$.

${ }^{a b}$ Different superscripts within a column indicate significant differences between values (LSD test, $P<0.05$ ).

to the effective development of embryos during heterotopic pregnancy and to the establishment of adaptive features in the progeny.

\section{Adrenocortical responses to stress stimuli in adult offspring}

The study of adrenocortical reaction to experimental social conflict was carried out in 2.5-3.0 month old purebred and hybrid males and males obtained by intraand interstrain transfer of embryos in two independent experiments in different seasons.

Experiment 1: pair-matched test. Two-way ANOVA revealed highly significant effects of experimental group $\left(F_{5253}=18.17\right.$ and $\left.P<0.001\right)$, social conflict $\left(F_{1253}=\right.$ 453.47 and $P<0.001)$ and their interaction $\left(F_{5253}=20.56\right.$ and $P<0.001)$ on the plasma concentrations of $11-\mathrm{OHCS}$. Under the basal condition, mice of the T-C group had higher concentrations of plasma 11-OHCS than did mice in the other groups (Fig. 1). A pair-matched test of mice from the same experimental group found a significant increase in plasma 11-OHCS concentrations. The maximal adrenocortical response to social conflict was observed in both groups of reciprocal hybrids. Purebred males of C and B groups had intermediate concentrations of glucocorticoids under stress; the hormonal reaction of $\mathrm{C}$ males to social conflict was greater than that of B males. Heterotopic transplantants T-B had minimal concentrations of plasma 11-OHCS. The different hormonal reactions of heterotopic transplantants T-B and purebred B males are not the result of manipulation during embryo transfer; homotopic transplantants T-C did not have different concentrations of 11-OHCS compared with purebred $\mathrm{C}$ males under social conflict.

Experiment 2: crowding. Two-way ANOVA also showed highly significant effects of experimental group $\left(F_{5136}=\right.$ 12.40 and $P<0.001)$, crowding $\left(F_{1136}=994.11\right.$ and $P<0.001)$ and their interaction $\left(F_{5136}=6.15\right.$ and $\left.P<0.001\right)$ on plasma 11-OHCS concentrations. The basal concentrations of 11-OHCS in plasma were identical in all groups except for the $\mathrm{C}$ group, in which the concentration was higher (Fig. 2). Crowding of 5-6 males (one from each group) revealed significant intergroup differences in plasma 11-OHCS concentrations. The maximal adrenocortical response to social conflict was found in homotopic transplantants T-C and, as in Expt 1, the lowest reaction was observed in heterotopic transplantants T-B. Males obtained from intra- and interstrain crosses had intermediate concentrations of plasma 11-OHCS. It should be noted that in Expt 1 differences between $C$ and $B$ males were observed and that this difference was also found in Expt 2.

Hence, activation of the adrenal cortex, which is an indicator of nonspecific adaptive responses to social stresses, depends on the genotype of mice and on the conditions of embryo development. The $\mathrm{C}$ strain surpassed the $B$ strain in both experiments. Hormonal reactions of hybrids changed depending on experimental conditions. The hormonal reaction was highest if mice of the same group were encountered in a pair-matched test. However, reactions of hybrids to crowding with mice of different groups were not different from those of the low reactive $B$ strain. Transplantation of embryos to mothers of the same genotype T-C either did not affect the adrenocortical responsiveness of adult offspring or surpassed this value in males of the mother's strain. Heterotopic transplantation led to a decrease in adrenocortical reactivity of the progeny T-B group revealing itself in both models of social conflict.

\section{Discussion}

The results of the present study show that plasma progesterone concentrations during the early stages of pregnancy are higher in interstrain crosses than in intrastrain crosses. High plasma progesterone concentrations during heterotopic pregnancy correlate with an increase in the progesterone content of uterine tissues in BALB/CLac females only. Progesterone content in tissues of purebred embryos is lower than in tissues of hybrids.

Studies of pseudopregnancy, as well as intra- and interstrain embryo transfer, offer an opportunity to analyse 

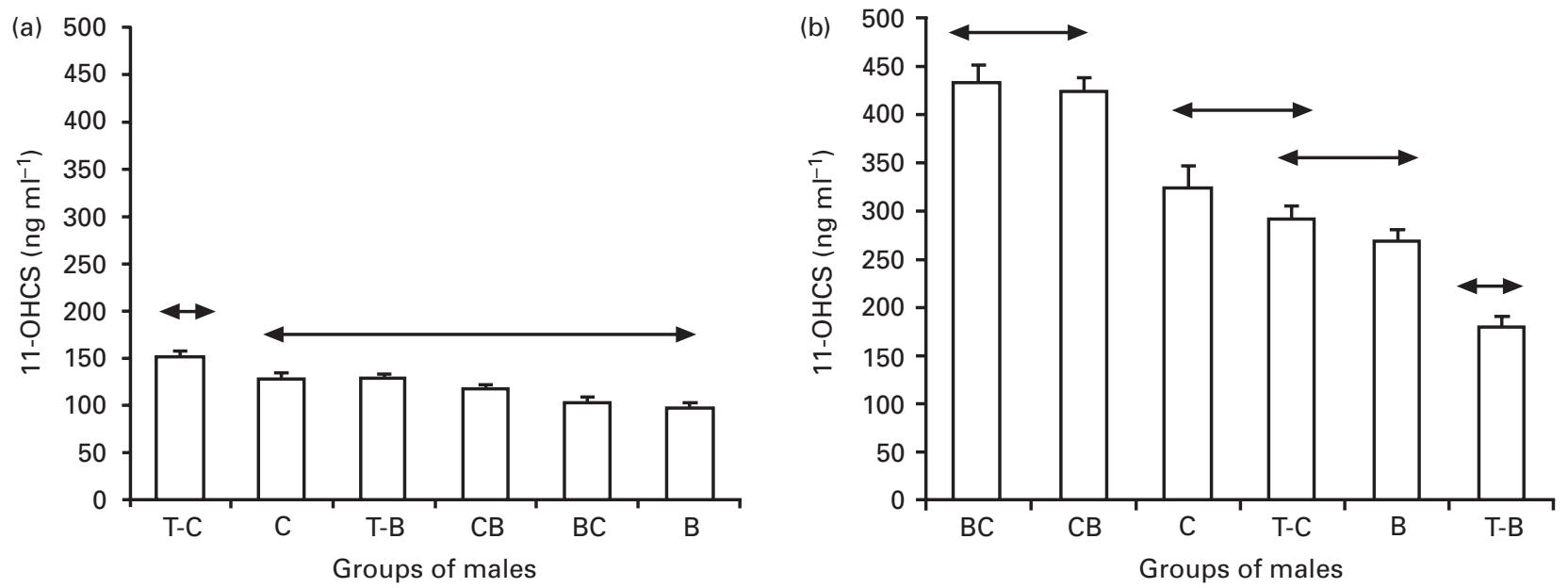

Fig. 1. Plasma 11-oxycorticosteroid (11-OHCS) concentrations (a) before and (b) after pair-matched tests with males of different experimental groups. Group C: progeny of purebred mating of BALB/cLac mice; group B: progeny of purebred mating of C57BL/6J mice; group CB: progeny of interstrain mating of BALB/CLac (female) and C57BL/6J (male) mice; group BC: progeny of purebred mating of C57BL/6J (female) and BALB/cLac (male) mice; group T-C: BALB/cLac mice obtained from homotopic embryo transfer to female BALB/CLac mice; and group T-B: C57BL/6J mice obtained from heterotopic embryo transfer to female BALB/cLac mice. Arrows above columns mean that combined they belong to homogeneous groups (LSD test).
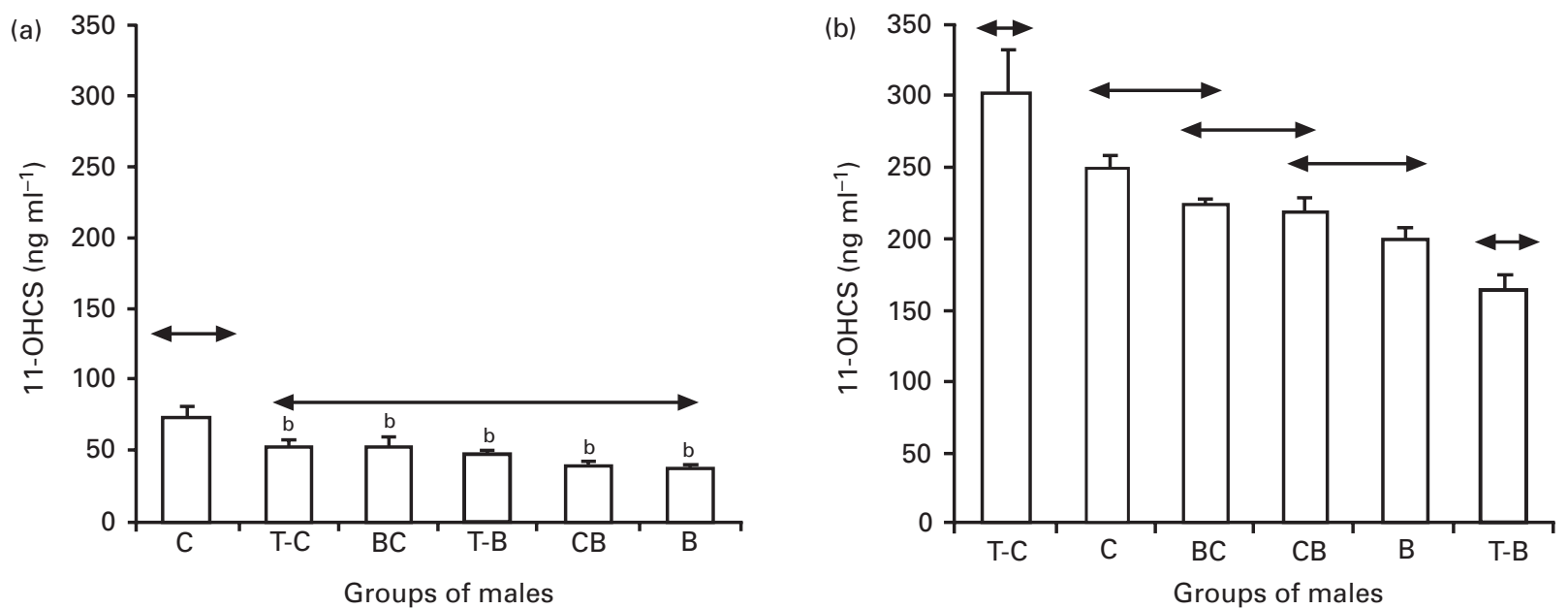

Fig. 2. Plasma 11-oxycorticosteroid (11-OHCS) concentrations (a) before and (b) after crowding of 5-6 males on the neutral arena. Group C: progeny of purebred mating of BALB/CLac mice; group B: progeny of purebred mating of C57BL/6J mice; group $\mathrm{CB}$ : progeny of interstrain mating of BALB/cLac (female) and C57BL/6J (male) mice; group BC: progeny of purebred mating of C57BL/6J (female) and BALB/CLac (male) mice; group T-C: BALB/CLac mice obtained from homotopic embryo transfer to female $\mathrm{BALB} / \mathrm{cLac}$ mice; and group T-B: C57BL/6J mice obtained from heterotopic embryo transfer to female BALB/CLac mice. Arrows above columns mean that combined they belong to homogeneous groups (LSD test).

three possible reasons for the increase in progesterone concentrations in plasma and tissues during heterotopic pregnancy. Two of these are concerned with the activation of the mother's immune system during heterotopic pregnancy, which could be due to either antigens of sperm fluid or antigens of embryos (James, 1965; En-Yu and Dawson, 1986; Govalo, 1987; Weetman, 1999). This conclusion is based upon the finding that lymphokines produced by immune cells have a wide range of neuroendocrine effects including ovarian secretion of progesterone (Rothwell, 1991; Rutanen, 1993; Seki et al., 1997). The basis for the third reason could be the effects of heterosis on the formation of gonadotrophin-like substances by hybrid embryos stimulated by ovarian endocrine function (Wiley, 1974; Levasseur, 1983; Alexander et al., 1998).

The similar plasma progesterone concentrations observed during homotopic and heterotopic pseudopregnancy showed that hormonal differences between intra- and interstrain 
mated females are not associated with sperm alloantigens. At the same time, transfer of purebred embryos revealed higher concentrations of plasma progesterone after heterotopic transfer than after homotopic transfer. Unidirectional changes of endocrine status observed in interstrain crosses and heterotopic transference point to a possible role of antigenic differences between fetus and mother, rather than heterosis, as a factor that stimulates ovarian progesterone production through immuno-endocrine interaction.

It has been shown that intrauterine conditions during heterotopic pregnancy facilitate postembryonic development (Evsikov and Morozova, 1977, 1978; Vagina, 1997; Evsikov et al., 1998). It is also well known that even brief changes in the endocrine status of pregnant females affect not only morphological, but also behavioural and physiological, features of adult offspring (vom Saal and Bronson, 1980; Dygalo and Naumenko, 1985; Naumenko and Maslova, 1985; Dygalo, 1988). The results of the present study demonstrate that, in parallel with factors such as pre- and postnatal stress, mother's diet (Hansson, 1989; Nelson, 1991) and embryo position in uterus (Clark and Galef, 1988; Clark et al., 1990, 1993), genetic similarity or dissimilarity of mother and fetus also plays a key role in influencing offspring fitness. For example, offspring fitness to emotional stress, caused by high population density in natural populations and in crossing in captivity, is higher in individuals with a low adrenocortical response to stress (Ganem, 1991; Moshkin et al., 1994; Lankin, 1996). In particular, it is expected that purebred males of B strain obtained by allogenic transplantation have the lowest adrenocortical reaction to stress that could increase their adaptability in conditions of high population density.

Thus, although modifications induced by heterotopic transplantation, such as progesterone concentrations in plasma and uterine tissues of pregnant females and embryos and embryo growth, have the same direction as during hybrid pregnancy, changes in other parameters occur in the opposite direction, for example, adrenocortical reaction of offspring to social conflict. Hence, mammalian evolutionary achievements, such as long-term intrauterine development, do not only afford embryo protection, but also act as a mechanism creating phenotypic diversity, which underlies genetic predetermined inter-relationships between the mother and fetus.

The authors would like to thank V. Danenberg for correcting the English, M. Carlier and unknown referees for their sincere interest in this study and their critical comments. This work was supported by grants from RFBS (Grant-99-04-49938).

\section{References}

Alexander H, Zimmermann G, Lehmann M, Pfeiffer R, Schone E, Leiblein S and Ziegert M (1998) HCG secretion by peripheral mononuclear cells during pregnancy Domestic Animal Endocrinology 5 377-387

Aliev MG and Guseinova NI (1986) Influence of chronic stress on time of pregnancy and functional status of hypothalamo-pituitary-adrenal system offspring (in Russian) Problemy Endocrinologii 32 79-83
Balashov YG (1990) Fluorimetric micromethod for assay of corticosteroids: comparison with other methods (in Russian) Physiologicheskyi Zhurnal 76 280-283

Barkley MS, Geschwind II and Bradford GE (1979) The gestational pattern of estradiol, testosterone and progesterone secretion in selected strains of mice Biology of Reproduction 20 733-738

Billington WD (1964) Influence of immunological dissimilarity of mother and foetus on size of placenta in mice Nature 202 317-318

Brown GM and Martin JB (1974) Corticosterone, prolactin, and growth hormone responses to handling and new environment in the rat Psychosomatic Medicine 36 241-247

Carlier M, Nosten-Bertrand M and Michard-Vanhee C (1992) Separating genetic effects from maternal environmental effects. In Techniques for the Genetic Analysis of Brain and Behavior pp 111-126 Eds D Goldowitz, D Wahlsten and RE Wimer, Elsevier Science Publishers, Paris

Clark MM and Galef BG (1988) Effects of uterine position on rate of sexual development in female Mongolian gerbils Physiology and Behavior 42 115-118

Clark MM, Malenfeant SA, Winter DA and Galef BG (1990) Fetal uterine position affects copulation and scent marking by adult male Mongolian gerbils Physiology and Behavior 47 301-305

Clark MM, Karpiuk P and Galef BG (1993) Hormonally mediated inheritance of acquired characteristics in Mongolian gerbils Nature 364 712

Clemens LE, Siiteri PK and Stites DP (1979) Mechanism of immunosuppression of progesterone on maternal lymphocyte activation during pregnancy Journal of Immunology 122 1978-1985

Cozard KM and Warner CM (1981) Specificity of $\mathrm{H}-2$ antigens expressed on mouse blastocysts Journal of Experimental Zoology 218 313-320

Duc-Goiran P, Mignot TM, Bourgeois C and Ferre F (1999) Embryo-maternal interaction at the implantation site: a delicate equilibrium European Journal of Obstetrics and Gynecology and Reproductive Biology 83 85-100

Dygalo NN (1988) Emotional reactivity of rats and their offspring after hormonal modification intrauterine development (in Russian) Zhurnal Vyshei Nervnoi Dejatelnosti 23 710-714

Dygalo NN and Naumenko EV (1985) Genetic aspects of hormonal modification stress reaction (in Russian) Geneticka $2012-21$

En-Yu L and Dawson WD (1986) Paternal antigen and progesterone effects on conceptus size in laboratory mice Biology of Reproduction 35 524-530

Evsikov VI and Morozova LM (1977) Role of genetic-physiological interaction of mother-foetuses in establishing mammalian viability and fertility. Report I. Embryonal development of mice in interstrain transference of blastocysts (in Russian) Genetika 5 826-839

Evsikov VI and Morozova L M (1978) Role of genetic-physiological interaction of mother-foetuses in establishing mammalian viability and fertility. Report II. Weight of embryos of mice of strain BALB, CBA and DBA development from transference of blastocysts (in Russian) Genetika 7 1264-1271

Evsikov VI, Osetrova TD and Belaev DK (1972) Genetics of animal fertility. Report IV. Embryonic mortality and its influence on fertility of mice strain BALB, C57BL and reciprocal hybrids (in Russian) Genetika 2 55-66

Evsikov VI, Gerlinskaya LA, Moshkin MP, Belogurova MP and Rogova OA (1991) Progesterone concentration in early stage of homo- and heterogenous pregnancy of mice (in Russian) Proceedings of Academy of Sciences USSR 319 494-497

Evsikov VI, Gerlinskaya LA, Moshkin MP, Potapov MA and Osetrova TD (1998) Genetic predetermined interaction of mother-foetus and its influence on adaptive properties of offspring (in Russian) Ontogenez 29 405-417

Fernandez N, Cooper J, Sprinks M, AbdElrahman M, Fiszer D, Kurpisz M and Dealtry G (1999) A critical review of the role of the major histocompatibility complex in fertilization, preimplantation development and feto-maternal interactions Human Reproduction Update 5 234-248

Ganem GA (1991) A comparative study of different populations of Mus musculus domesticus: emotivity as an index of adaptation to commensalism Comparative Biochemistry and Physiology 4 531-536 
Govalo VI (1987) Immunology of Reproduction (in Russian). Medicine Moskow, Moscow

Grossman CJ (1984) Regulation of the immune system by sex steroids Endocrine Reviews 5 435-455

Hansson L (1989) Trashing or delay effects in microtine reproduction? Acta Teriol 34 125-132

Heap RB, Flint AP, Gadsby JE and Rice C (1979) Hormones, the early embryo and the uterine environment Journal of Reproduction and Fertility 55 267-275

Henry C, Kabbaj M, Simon H, Le Moal M and Maccari S (1994) Prenatal stress increases the hypothalamo-pituitary-adrenal axis response in young and adult rats Journal of Neuroendocrinology 6 341-345

James DA (1965) Effects of antigenic dissimilarity between mother and foetus on placental size in mice Nature 202 613-614

Kinsley C and Svare B (1986) Prenatal stress reduces intermale aggression in mice Physiology and Behavior 36 783-786

Kiochisa T, Kazuko I and Yasuro T (1977) Parallel shift in circadian rhythms of adrenocortical activity and food intake in blinded rats and rats exposed to continuous illumination Endocrinology 100 1097-1107

Krco CJ and Goldberg EM (1977) Major histocompatibility antigens on preimplantation mouse embryos Transplantation Proceeding IX $1367-1370$

Lankin VS (1996) Domestication Behavior in Ungulate Animals and its Adaptive Role (in Russian). Nauka, Novosibirsk

Levasseur M (1983) Utero-ovarian relationships in placental mammals: role of uterus and embryo in the regulation of progesterone secretion by the corpus luteum. A review Reproduction Nutrition Development 23 793-816

McCormic CM, Smythe JW, Sharma S and Meaney MJ (1995) Sex-specific effects of prenatal stress on hypothalamo-pituitary-adrenal responses to stress and brain glucocorticoid receptor density in adult rats Developmental Brain Research 84 55-61

Mathialagan N and Roberts RM (1994) A role for cytokines in early pregnancy Indian Journal of Physiology and Pharmacology 38 153-162

Medawar PB (1953) Some immunological and endocrinological problems raised by the evolution of viviparity in vertebrates Symposium of the Society for Experimental Biology 7 320-328

Michael SD, Geschwind II, Bradford GE and Stabenfeld G H (1975) Pregnancy in mice selected for small litter size: reproductive hormone levels and effect of exogenous hormones Biology Reproduction 12 400-407

Morris H, Edwards J, Tiltman A and Emms M (1985) Endometrial lymphoid tissue: an immunohistological study Journal of Clinical Pathology 38 644-652

Morris H, Emms M, Visser T and Timme A (1986) Lymphoid tissue of the normal fallopian tube: a form of mucosa-associated lymphoid tissue (MALT)? International Journal of Gynecological Pathology 5 11-22
Moshkin M, Gerlinskaya L and Evsikov V (1994) Variability of stressreactivity in a natural population of water vole, Arvicola terrestris. Polish Ecological Studies 20 409-415

Munroe JS (1971) Progesteroids as immunosuppressive agents Journal of Reticuloendothelial Society $9361-375$

Naumenko EV and Maslova LN (1985) Stress in early ontogenesis and reactivity of hypothalamo-pituitary-adrenal system in adult rats Endocrinologica Experimentalis 19 171-178

Nelson RJ (1991) Maternal diet influences reproductive development in male prairie vole offspring Physiology and Behavior 50 1063-1066

Rothwell NJ (1991) The endocrine significance of cytokines Journal of Endocrinology 128 171-173

Rutanen E (1993) Cytokines in reproduction Annals of Medicine 23 343-347

Seki H, Zosmer A, Elder MG and Sullivan MH (1997) The regulation of progesterone and hCG production from placental cells by interleukin- $1 \beta$ Biochimica et Biophysica Acta 2 342-348

Siiteri PK and Stites DP (1982) Immunologic and endocrine interrelationships in pregnancy Biology of Reproduction 26 1-4

Spina V, Aleandri V, Paccharotti A and Salvi M (1998) Immune tolerance in pregnancy. Maternal-fetal interactions Minerva Ginecologica $\mathbf{5 0}$ 533-537

Szekeres-Bartho J, Kinsky R, Kapovic M, Varga P and Chaouat G (1991) Progesterone dependent immunomodulation Reproductive Biology $\mathbf{9 3}$ 141-146

Udenfriend S (1962) Fluorescence Assay in Biology and Medicine. Academic Press, New York

Vagina IN (1997) Role of Genotypes and its Interaction in Individual Development of Mice (Mus musculus) (in Russian) PhD Thesis, University of Kiev

vom Saal FS and Bronson FY (1980) Sexual characteristics of adult female mice are correlated with their blood testosterone levels during prenatal development Science 208 597-599

Warner CM, Brownell MS and Ewoldsen MA (1988) Why are embryos not immunologically rejected by their mothers? Biology of Reproduction $\mathbf{3 8}$ $17-29$

Weetman AP (1999) The immunology of pregnancy Thyroid 9 643-646

Wiley LD (1974) Presence of a gonadotropin on the surface of preimplantated mouse embryos Nature 252477

Wilmut I, Sales DI and Ashworth CJ (1986) Maternal and embryonic factors associated with prenatal loss in mammals Journal of Reproduction and Fertility 76 851-864

Revised manuscript received 26 July 2000.

Accepted 20 October 2000. 